\title{
Peculiarities of current sensors used in contemporary electric energy metering devices
}

\author{
Vitalii Volokhin, \\ Illia Diahovchenko \\ Sumy State University, \\ Rymskogo-Korsakova St. 2, \\ 40007 Sumy, Ukraine \\ E-mail ilya.dyagovchenko@gmail.com
}

\begin{abstract}
An electricity meter is a tool that determines the amount of electricity transferred to the network by a producer and consumed by electrically powered loads. Metering devices are composed of sensitive sensors that simultaneously measure currents and voltages and a microprocessor, which calculates required values basing on the received data. This article gives an overview of the most common current sensors, which are used in contemporary electricity metering devices. Their principles, advantages and disadvantages are reviewed, conclusions about the external influences on the sensors, which can lead to the incorrect operation of a meter and wrong definition of consumed electricity, are made.
\end{abstract}

Keywords: electric energy meter, current sensor, hall-effect sensor, shunt, resistive divider, current transformer

\section{INTRODUCTION}

To determine the amount of energy consumption and analyze its quality parameters (e.g., voltage sags and swells, higher harmonics), electronic meters need information about the levels of current and voltage in the network. The accuracy of energy metering device is a function of measurement error, which depends on the precision (sensibility) of current and voltage sensors [1]. The definition of current value is considered to be more challenging because it requires a wider range of measurement and processing of a wider range of frequencies that are present in the current signal. The most common current sensors used for electricity metering devices are resistive shunts, Hall-effect sensors and current transformers [1].
Current sensors implemented on the basis of the above methods have their advantages and disadvantages, which define areas of their application.

\section{RESISTIVE SENSORS}

The method of direct measurements or resistive method is used quite often.

The simplest current and voltage sensing elements are precision resistive sensors. Accordingly, a current shunt measures operating current, and a voltage divider measures operating voltage [8]. The principle of their work is based on the ratio between current and voltage drops across the resistor, which is described by Ohm's law.

Current shunt (Fig. 1) is included directly in the gap phase wires. Its main advantages are: 
(a)

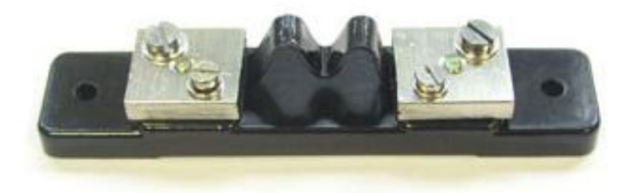

(b)

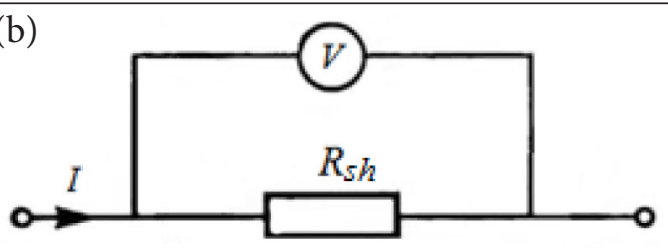

Fig. 1. Resistive current sensors: (a) appearance, (b) operation principle

- low cost;

- does not require an external power source;

- ability to measure both constant and alternating currents;

- direct measurement technique provides high accuracy (error less than 1\% [3]);

- ease of implementation;

- high linearity (linearity error does not exceed $1.25 \%$ [3]);

- small size;

- stability of temperature coefficient (TC does not exceed $0.01 \%$ [2]).

Along with the advantages shunts have a number of serious drawbacks:

1. The power loss due to shunt heating:

$$
P=I^{2} \cdot R_{s h}
$$

where $I$ is the current that flows through the phase wire of the electric meter and through the shunt, respectively, $\mathrm{A} ; R_{s h}$ is current shunt's resistance, $\Omega$.

For example, for the energy meter designed with rated current 5(50) A we can apply the shunt with resistance $R_{s h}=400 \mu \Omega$ [8]. It's easy to determine that at maximum current, according to the equation (1), this item highlights the spurious power of $1 \mathrm{~W}$. Firstly, it causes the increase of electricity consumption by the meter in total. Secondly, the shunt heats significantly and changes its resistance (a small non-linearity of the characteristic is present), which affects the measurement accuracy. In the conditions of the difficult cooling the latter problem is essential [7].

2. The presence of the internal (parasitic) inductance of the shunt (on the order of 0.1-10 nH) leads to the bandwidth limitation and the growth of error under the action of high-frequency signals.

3. Lack of galvanic isolation. Through this high-voltage is supplied on the metering device's microchip, which complicates screening and requires heightened protection against electric shock.

4. The presence of noise and impulse disturbances affects the measuring circuit quite critically; therefore, using of special protective filters that introduce phase distortion in the measurement is required [8].

At low currents the shunt must have higher resistance, to make the value of voltage drop on it sufficient for the recording device. To amplify or process the voltage allocated on the current-sense resistor, a differential amplifier or a comparator with sufficient common mode rejection ratio (CMRR) is required, particularly in the vicinity of current-carrying elements.

High-quality low-resistivity current resistors are produced by companies:

- Vishay (Vishay Intertechnology),

- Panasonic Industrial Company (Electronic Components Division),

- KOA (KOA Speer Electronics),

- IRC (TT Electronics).

In practice, the value, dissipated power, and temperature coefficient (TC) are selected so that during resistive sensor operation its resistance deviations, due to thermal heating, don't exceed $0.1 \%$ (1000 ppm) with a maximum voltage drop about $100 \mathrm{mV}$ [3].

To eliminate the influence of parasitic inductance, metal-film resistors (for example, WSF series from Vishay company) or metal-foil resistors (e. g. CSM series from Vishay company) can be used.

Wirewound resistors of WSC series are sealed by epoxy resin or thermoplastic, and the latest series of WSZ by cement or silicon. In the wirewound resistors of WSN series parasitic inductance can be reduced by using bifilar winding [3]. 


\section{SENSORS BASED ON HALL EFFECT}

Disadvantages of resistive shunts are forced to look for other current measuring methods. An alternative in this regard are current sensors based on the Hall effect (opened by Edwin Herbert Hall in 1879). The appearance of such a device is shown in Fig. 2a.

In the simplest case, this phenomenon can be described in Fig. 2b. Even the electric current $I$ flows through the thin plate located in a weak magnetic field $B$ under the action of electric intensity $E$. The magnetic field will deflect electrons from their movement along or against the electric field to one of the plate's faces [10].

Thus, the Lorentz force will lead to the accumulation of positive charge near one face of the plate and negative near the opposite face. The charge will be accumulating until the electric field of charges $E_{c h}$, which arose under the influence of the magnetic field, does not counterbalance the magnetic component of the Lorentz force:

$$
e E_{c h}=\frac{e \Delta \varphi}{a}=e v B \Rightarrow E_{c h}=v B
$$

where $e$ is the elementary charge of a charged particle (electron), $C ; \Delta \varphi$ is the transverse potential difference, $\mathrm{V} ; a$ is the width of the plate, $\mathrm{m} ; v$ is the speed of electrons, $\mathrm{m} / \mathrm{s}$.

If express the current through the current density J:

$$
I=J S=n e v S,
$$

where $n$ is the concentration of elementary charges; $S$ is the cross-sectional area of the plate, $\mathrm{m}^{2}$. Get [10]:

$$
\Delta \varphi=\frac{I}{n e a d} B a=\frac{1}{e n} \frac{I B}{d}=R_{H} \frac{I B}{d}
$$

where $d$ is the thickness of the plate, $\mathrm{m}$.

The correlation between the field of charges $E_{c h}$ and charge density in a magnetic field $J \cdot B$ is called the Hall coefficient:

$$
\Delta \varphi=\frac{I}{n e a d} B a=\frac{1}{e n} \frac{I B}{d}=R_{H} \frac{I B}{d}
$$

The Hall constant depends on the substance. In modern Hall-effect sensors sensitive elements are made from semiconductors, because their currents are several times smaller and the voltage is same times bigger. The first Hall sensors were created in the early 70 -ies of the 20th century on the basis of germanium and silicon. Then they were replaced by sensors based on thin epitaxial layers. Later there was a similar device based on homo- and heteroepitaxial layers of materials group A3B5: GaAs (gallium arsenide), InAs (indium arsenide), InSb (indium antimonide) and others [2].

To create a basic current sensor it is sufficient to take a magnetic core, feed through it a phase conductor of the measuring circuit and arrange

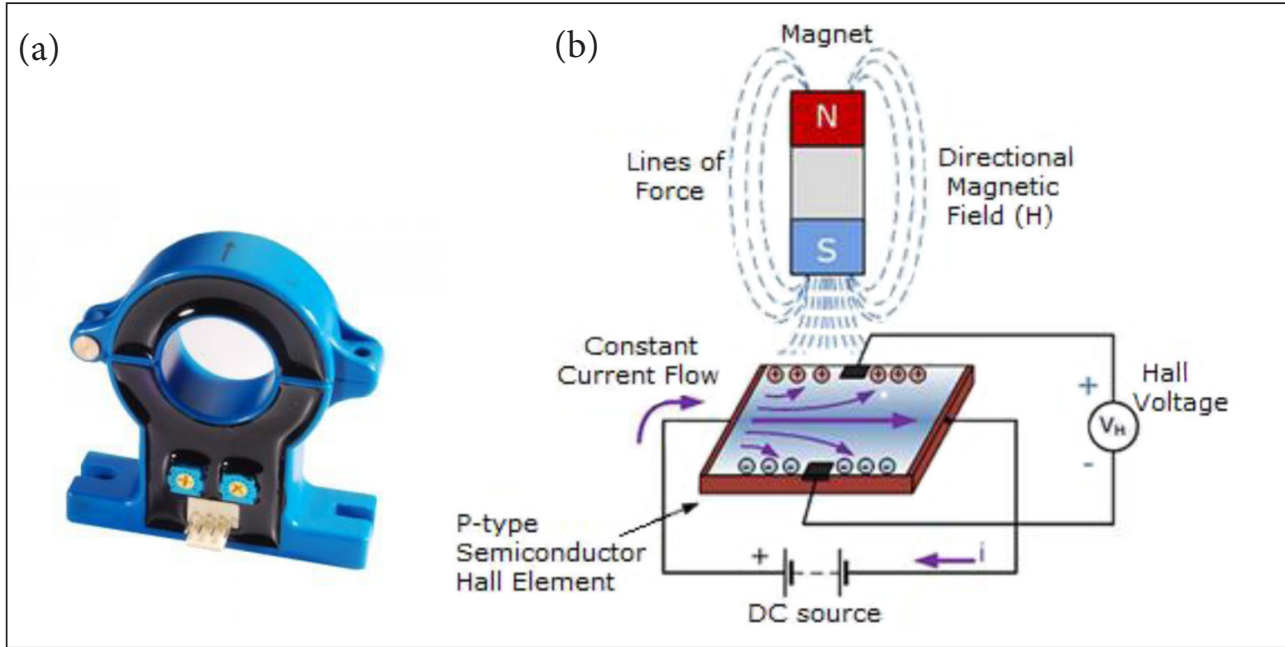

Fig. 2. Current sensors based on Hall effect: (a) appearance, (b) explanation of the Hall effect principle 
the Hall element in the context of magnetic core. As the result the opened (direct) type Hall sensor will be received (Fig. 3). The advantage of such sensors is the simplicity of design. Drawback the presence of a magnetic bias of the core, which leads to increase of readings' nonlinearity [11]. In addition, they have an output shift at zero current [3].

To avoid the latter negative phenomena the compensation winding is wounded on the core and it carries the current, proportional to the measured current. Get a closed-loop (compensation) type Hall sensor [11].

The principle of compensation Hall-effect current sensors' operation is explained with a diagram (Fig. 4). The primary conduit with the primary (measured) current passes through the sensing element, which is most often made from magnetically soft material. The magnet- ic flux created by this current concentrates in the magnetic circle and transforms by the Hall sensor, located into the air gap. The signal from the Hall sensor is amplified and supplied to the magnetic core's winding. The magnetic field, generated by this coil's current, compensates the magnetic field of the measured current.

In this case the Hall sensor works as an element of comparison in a very narrow region of the conversion characteristic. It provides low conversion nonlinearity and low dependence on individual variation of Hall sensors' parameters. The compensating current is simultaneously the outgoing current of the sensor with linear current output [2].

For the described device, the next equation is valid:

$$
N_{P} I_{P}=\mathrm{N}_{S} I_{S}
$$
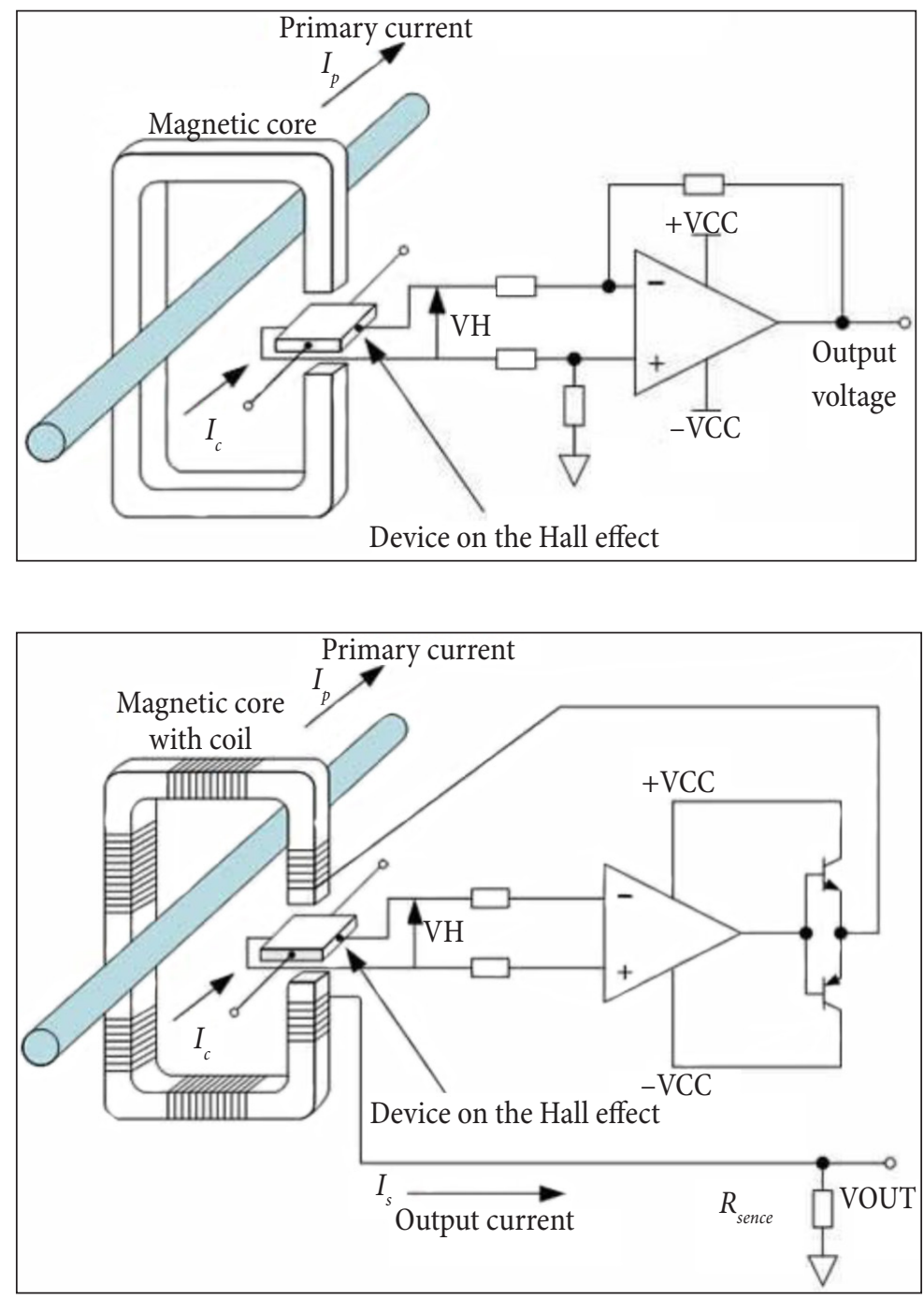

Fig. 3. Open type Hall-effect current sensor

Fig. 4. Compensation type Hall-effect current sensor 
where $N_{P}, N_{s}$ is number of turns of primary and secondary (compensation) windings of the sensor, respectively $I_{P}, I_{S}$ are currents of primary and secondary (compensation) windings of the sensor, respectively, A.

The advantages of these sensors include:

- high accuracy in a wide range of frequencies;

- excellent linearity;

- galvanic interchange;

- fast response time (in modern samples less than $3 \mu \mathrm{s}$ ) [4];

- light weight;

- low temperature drift;

- small internal electricity consumption;

- usually don't have output shift at zero current [3].

However, there are some disadvantages:

1. The accuracy depends on the number of coils of the compensation winding, so the closedtope Hall sensors approach in their cost to current transformers.

2. Sensitive to external magnetic fields and currents flowing in nearby conductors. Therefore, these sensors are not suitable for electricity meters that are installed in electrical circuits with existing electric distortion [1].

3. Accuracy depends on the location of the conductor with measured current [6].

The most famous manufacturers of current sensors based on Hall effect:

- LEM (Switzerland),

- ABB (Department in France),

- Honeywell Technologies (USA),

- Allegro MicroSystems (USA),

- 3E Sensor Co.Ltd (PRC),

- Ningbo CSR (China),

- Sentron AG (Switzerland).
Nowadays, sensors built on the basis of electronic technologies, which don't require a magnetic core, are often used. The absence of the magnetic core leads to diminishing of unit's weight and dimensions.

In addition, such devices can work for a long time under the maximum current without reducing accuracy characteristics.

Allegro MicroSystems company produces small-sized integrated current sensors series ACS750/752 with stabilization by interrupt (Dynamic Offset Cancellation), based on Hall-effect sensors. Stabilization by interrupt is a periodic (with a frequency of $0.17 \mathrm{MHz}$ ) switching of quadrature (perpendicular to each other) terminals of the Hall element by using an output switch with the subsequent differential amplification, slinging and remembering the flat plot of the pulse. This allows compensate some bias voltage's components (including at zero current) due to geometrical inhomogeneities, gradient resistances, piezoresistive elements, etc. [3].

\section{TRANSFORMER CURRENT SENSORS (CURRENT TRANSFORMERS)}

The current transformer (CT) is shown on Fig. 5a and performs the role of a sensor, via which information arrives to the measuring parts of an electricity meter. The common working principle can be explained using Fig. 5b. The primary winding of the current transformer is put directly in the measuring circle. The secondary winding is short-circuited on the resistance $Z_{H}$ (a precision resistor is used).

The current $I_{1}$, which flows through the winding, produces a magnetic flux:

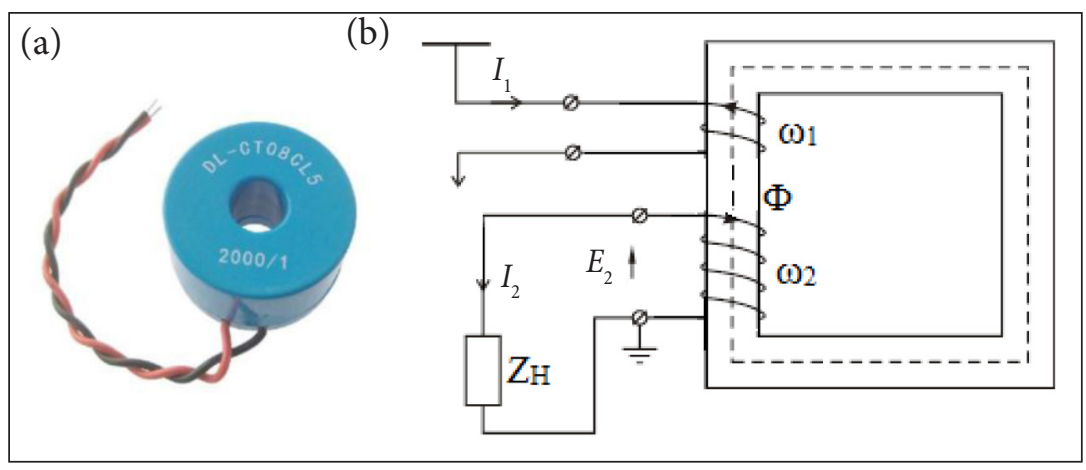

Fig. 5. Current transformers: (a) appearance, (b) operation principle 


$$
\Phi_{1}=I_{1} \omega_{1}
$$

where $\omega_{1}$ is the number of turns in the primary winding.

Under the action of this flux EMF $E_{2}$ is induced in the secondary winding. Current $I_{2}$ flows through the coil [13].

If we ignore losses, then:

$$
I_{1} \omega_{1}=-I_{2} \omega_{2} \Rightarrow I_{2}=-I_{1} \frac{\omega_{1}}{\omega_{2}}=-\frac{I_{1}}{n_{8}},
$$

where $n_{6}=\frac{\omega_{2}}{\omega_{1}}$ is turn transformation ratio.

In manufacturer's documents on the current transformer sensors nominal transformation ratio is specified:

$$
n_{m}=\frac{I_{1 \text { rat }}}{I_{2 \text { rat }}}
$$

where $I_{1 \text { rat }} I_{2 \text { rat }}$ are, accordingly, rated currents of the primary and secondary windings, A.

If we ignore losses, then $n_{\mathrm{B}}=n_{\mathrm{T}}$.

In fact, $I_{2}$ is different from the calculated value. Part of the current $I_{1}$ is spent for magnetization flux creation:

$$
\begin{aligned}
& I_{2}=-\frac{\left(I_{1}-I_{m a g}\right)}{n_{6}}=\left(-I_{1}+I_{m a g}\right) \frac{\omega_{1}}{\omega_{2}}, \\
& \underbrace{I_{2} \omega_{2}}_{\Phi_{2}}=\underbrace{-I_{1} \omega_{1}}_{-\Phi_{1}}+\underbrace{I_{m a g} \omega_{1}}_{\Phi_{n}} .
\end{aligned}
$$

The ideal mode for measuring current transformer operation is short-circuit of secondary winding. In this mode the induced current flows through the secondary circuit of CT. It creates the secondary magnetic flux in the magnetic coil, which compensates the magnetic flux from the current of primary circuit. As a result, in a stationary mode in the core there is established the total magnetic flux, which is close to zero $\Phi \approx 0$. This flux induces a small electromotive force in the secondary winding, due to which a current, proportional to the current value in the primary winding, is supported in the secondary winding [8].

In electric energy metering devices, two types of current transformer sensors are commonly used:

1. Loaded to a precision resistor. Such samples typically have a magnetic core of amorphous or nanocrystalline alloys. The output voltage taken from the resistor is proportional to the primary winding's current.

2. Differential transformers that operate in shock excitation mode. They don't usually have a magnetic core (air type). The transformer's output voltage is proportional to the rate of change of the primary current $(d i / d t)$.

Transformer type sensors have the following advantages:

- practically don't consume electricity (no losses) [3];

- provide galvanic isolation between the windings with a high breakdown voltage, thus the circuit is not fed with a high potential and it is easy to make screen protection;

- no need to use an integrator because the output voltage is directly proportional to the current's magnitude [1];

- transformation ratio is easily maintained at industry and always remains constant [8];

- quench the impulse noises in the measuring circuit without additional filters;

- absence of bias voltage at zero current values [3];

- do not require a separate power source;

- provide a minimum phase shift between the measuring circuits of voltage and current, because filtering of the measuring signal is carried by transformer's self-inductance [8].

The disadvantages of current sensors on the basis of current transformers include:

1. Most transformer sensors have an iron core. When a constant component (occurring through the unbalance load) is present in the primary current and during the flow of currents higher than the rated value, there occurs magnetic saturation of the core, which leads to irreversible deterioration of the conversion accuracy [1].

2 . The cost is much higher than that of resistive elements and, as a rule, dominated by the cost of the Hall-effect sensors.

3. Inability to use in DC circuits (usually work on the network frequency of 50, 60 or $400 \mathrm{~Hz}$ ).

Well-known manufacturers of current transformer sensors are:

- Inductive Technologies, LLC,

- CR Magnetics,

- NK Technologies.

To solve the problem of magnetic saturation of the core it is made from materials with high 
magnetic permeability. This, in turn, reduces thermal stability and increases a phase shift in the measuring circuit [3].

CT sensor's fallibility comprises a current error (infelicity of the actual transformation ratio) and angular error (phase difference between the currents of primary and secondary windings). Errors are determined by two factors:

- limited magnetic permeability of the magnetic core;

- non-zero value of the load resistance.

However, the smaller the transformer's error (fallibility), the less the magnetic resistance of the magnetic core, i.e. the greater material's magnetic permeability, the greater the cross section of the core and the less its length and also the less its secondary load (ideal case - a short-circuit mode). Magnetic permeability depends on magnetic field intensity and is almost constant only in the region of weak fields. Since transformers operate in weak resulting fields it is necessary to use materials with high initial magnetic permeability [8].

\section{CONCLUSIONS}

The article describes three basic types of current sensors that are used in contemporary electric energy metering devices. Resistive sensors are characterized by low cost, high accuracy and capability to measure both direct (DC) and alternating (AC) currents. Their disadvantages include internal own power losses (heat dissipation on the resistor) and the presence of parasitic inductance. The latter makes these sensors sensitive to noise and impulse interferences. Thus, meter's readings can be distorted by high-frequency signals impact.

Current sensors based on the Hall effect have a high linearity, low power consumption (for supplying of the internal source) and provide high measurement accuracy. They can be used in meters both AC and DC (e. g. in railway networks). Devices are sensitive to external magnetic fields and induced potentials, which are generated by currents in close located conductors. Under the action of external magnetic field readings of the metering device can be changed.

The advantage of the induction based sensors is the presence of galvanic isolation with high breakdown voltage. Due to the self-inductance they absorb and carry out impulse noise and filter the measured signal. However, in the presence of a constant component and the currents higher than rated, the core of CT is saturated, that leads to a significant decrease of measurement accuracy. In addition, current transformers are sensitive to magnetic fields and therefore require protective screens installation.

Received 16 January 2017 Accepted 20 March 2017

\section{References}

1. O’Driscoll E., O’Donnell G. E. Industrial power and energy metering - a state-of-the-art review. Journal of Cleaner Production. 2013. Vol. 41. P. 53-64.

2. Portnoj G. Sovremennye magnitochuvstvitel'nye datchiki Holla i pribory na ih osnove. [Modern magnetically sensitive Hall sensors and devices on their basis]. Vestnik Avtomatizacii. 2013. Vol. 39. No. 1. P. 7-12.

3. Danilov A. Sovremennye promyshlennye datchiki toka. [Modern industrial current sensors] Sovremennaja jelektronika. 2004. No. 1. P. 26-35.

4. LEM. Izolirovannye datchiki toka i naprjazhenija: Harakteristiki - Primenenie - Raschety. [Isolated current and voltage sensors: Characteristics - Applications - Calculations].

5. Kara S., Bogdanski G., Li W. Electricity metering and monitoring in manufacturing systems, glocalized solutions for sustainability in manufacturing. Proceedings of the 18th CIRP International Conference on Life Cycle Engineering, 2011. P. $1 \mathrm{e} 10$.

6. Ripka P. Electric current sensors: a review. Measurement Science and Technology. 2010. Vol. 21. No. 11. P. 112001.

7. Iwansson K., Sinapius G., Hoornaert W., Middelhoek S. Measuring current, voltage and power. Vol. 7. Elsevier, 1999.

8. Ashmarov Ju. V. Nekotorye aspekty primenenija datchikov $\mathrm{v}$ schetchikah jelektrojenergii [Particular aspects of sensors application in electric energy meters]. http://www.eltranstech.ru/products/nekotorye-aspekty-primeneniya-datchikov-v-schetchikah-elektroenergii/ 
9. Sysoeva C. Datchiki magnitnogo polja. [Magnetic field sensors]. Komponenty i tehnologii. 2012. No. 1. P. 19-32.

10. Landau L. D., Lifshic E. M. Teoreticheskaja fizika. Jelektrodinamika sploshnyh sred [Course of theoretical physics. Electrodynamics of continuous media], Vol. VIII. Moscow: Nauka, 1982. P. 309.

11. Kashkanov A. Datchiki i mikrokontrollery [Sensors and microcontrollers]. 2015. https://geektimes.ru/post/255126/

12. Chekmarev A. Datchiki toka $i$ naprjazhenija $A B B$ - ot pechatnoj platy do preobrazovatelej-gigantov [Current and voltage sensors $\mathrm{ABB}$ - from circuit boards to transducers giants]. Silovaja Jelektronika. 2006. No. 3. P. 56-57.

13. Volokhin V. V., Diahovchenko I. M. The use of nanocrystalline and amorphous materials for electric energy metering improvement and reducing the effects of external magnetic fields. Nanomaterials: Application \& Properties (NAP), International Conference on. IEEE, 2016. P. 02NEA03-1-02NEA03-3.
Vitalii Volokhin, Illia Diahovchenko

SROVĖS DAVIKLIŲ, NAUDOJAMŲ ŠIUOLAIKINIUOSE ELEKTROS ENERGIJOS MATAVIMO PRIETAISUOSE, YPATUMAI

\section{Santrauka}

Elektros skaitiklis yra prietaisas, nustatantis elektros kiekį, gamintojo perduodamą i tinklą ir sunaudotą maitinamų apkrovų. Matavimo prietaisai susideda iš jautrių daviklių, kurie matuoja sroves ir įtampas, taip pat mikroprocesoriaus, kuris iš gautų duomenų suskaičiuoja reikiamus dydžius. Straipsnyje pateikiama dažniausiai pasitaikančių srovès daviklių, naudojamų šiuolaikiniuose elektros matavimo prietaisuose, apžvalga. Aprašomi jų principai, pranašumai ir trūkumai, pateikiamos išvados apie išorinius poveikius, galinčius sukelti netikslų skaitiklio darbą ir klaidingus sunaudotos elektros energijos parodymus.

Raktažodžiai: elektros energijos skaitiklis, srovès daviklis, Hall'o efekto daviklis, šuntas, varžinis įtampos dalytuvas, srovès transformatorius 